
\title{
R Reserach S Suare \\ Effect of Recycling Digestate Filtrate for Cow Dung Dilution on Biogas Production
}

INOUSS MAMATE ABAKAKA ( $\square$ inoussmamate.88@gmail.com )

National committee for Development of Technologies

TIZE KODA Joël

National Advanced School of Engineering, Maroua

\section{Research Article}

Keywords: digestate, filtrate, biogas, substrate, water

Posted Date: March 3rd, 2022

DOI: https://doi.org/10.21203/rs.3.rs-1365752/v1

License: (c) (i) This work is licensed under a Creative Commons Attribution 4.0 International License. Read Full License 


\section{Abstract}

Biogas production in the Sahelian zone faces the problem of water shortage during the dry season. This study was initiated in the bioscience laboratory at the University of Maroua with the objective of improving the accessibility of households to biogas in water scarcity conditions. Also another aim is to recycle the filtrate of the digestate into a new dilution of the substrate for biogas production. Thus, the Cow Dung (CD) digestate from the biogas unit was filtered. Two types of filters were made: filter with sand and cotton and filter with sand, biochar and cotton. The filtrate obtained was used to make five treatments with $C D$ to feed mini biodigesters (1st generation) of 1 liter each. After a HRT of 30 days, the digestate from the 1 st generation was again filtered into the same treatments (2nd generation). During the anaerobic digestion; the production and $\mathrm{pH}$ of each treatment repeated three times were evaluated. The effect of water recycling and the type of filtration were analyzed. This study shows that the dilution of $\mathrm{CD}$ with the filtrate from the 1 st generation significantly improves on the production of biogas by $47 \%$ compared to that of dung diluted with ordinary water. In the 2 nd generation, dilution with ordinary water provided the best production which is $7 \%$ higher than that obtained from the filtrates without biochar. As the $\mathrm{pH}$ is concerned, it varies between 6 and 7.5 when filtrates are used. It was more acidic when water has been used.

\section{Introduction}

Energy is the basis for development. However, in recent years, the world has been facing huge energy problems. Fossil fuels are becoming increasingly scarce, even though they are the most widely used sources [1]. However, wood is the main source of energy in most African countries [2]. It is used for cooking, heating, and crafts [3]. When considering the total amount of wood used as an energy source, Africa consumes $90 \%$ of the wood from the forest (natural and planted) [4], [5]. According to the National Institute of Statistics (NIS), $96.3 \%$ of the population in rural areas in Cameroon depend mainly on wood energy to prepare meals [6]. This proportion is higher in the Far North Region who's environment is closely desertic. The almost exclusive dependence on firewood explains the strong pressure of the population on the rare woody plants that found in its already naturally fragile ecology. This situation has created a large market for wood energy in urban areas [7]. According to Tunk et al.,(2016), the wood energy trade is one of the four main economic activities in the city of Maroua [8]. A study conducted by MINFOF (2014) revealed that demand for this fuel was much higher than supply [9]. It indicated a deficit of $45 \%$ in 2022 . The threat appears to be increasingly intense, especially in a region that is the poorest and declared by the Cameroonian government as an economically affected area. Initiatives are being taken to offer the population an alternative source of cooking energy. The one aiming at the promotion of biogas in rural areas seems to be the most adequate. However, the constraint linked to the availability of water for the proper functioning of the biodigester must be overcome. Indeed, the Far North region, located in the Sahelian zone, has a low water resources. Sometimes water points are very rare and the whole village converges there in order to get a few liters after waiting for hours [10]. The Mandara Mountains Development Authority (MIDIMA) quoted by Yopo [11] estimated the rate of drinking water supply to be 1 
water point for about 1737 people. According to Yopo [11], most wells and boreholes up to $61 \%$ are nonfunctional due to water shortage during the dry season. Women and children can sometimes walk up to $10 \mathrm{~km}$ to have access to a water point. Water shortages has its peak in March and April [12],[13]. In this context where access to water is difficult, the normal operation of a biodigester to generate biogas in order to substitute firewood is almost impossible in some localities. Indeed, anaerobic digestion requires enough water daily to dilute the substrate. The digestate discharged from the system is almost liquid. We, therefore, questioned whether the water in the digestate could be recycled for reuse in the biodigester to continue producing biogas. This concern motivated us to initiate this study on the recycling of the water from digestate for biogas production. The main objective is to evaluate the effect of the digestate filtrate on anaerobic digestion of the cow dung. Specifically, this is to test the filtration of the digestate, to measure the biogas production and $\mathrm{pH}$ of cow dung diluted essentially with the filtrate.

\section{Material Et Methods}

\subsection{Digestate Filtration Test}

For filtration, digestate was collected from a city biogas plant. Two types of sand filters were made with some reference to the biosand filter principle [14]. The first one consists of a layer of sand $(8 \mathrm{~cm})$, gravel $(5 \mathrm{~cm})$, biochar $(3 \mathrm{~cm})$ and cotton $(0.2 \mathrm{~cm}$ thick) $[15,16]$. The second one differs from the first only by the absence of the biochar layer. The size of sand particles used is $0.8 \mathrm{~mm}$. For the gravel, it varies between 6 $\mathrm{mm}$ and $12 \mathrm{~mm}$ [17],[18]. The following Fig. 1. shows the experimental filtration setup.

\subsection{The biogas production with recycled water}

The biogas production was carried out with cow dung. Two generations of the filtrate were tested. The first generation is the filtrate obtained after the first biogas production cycle. The second generation is the filtrate from the digestate of the second production cycle. This is water that has already been used twice in a biodigester. The filtrate obtained from each type of filter was subjected to four treatments and a control, which are repeated three times. The filtrate is used to dilute fresh cow dung at a rate of 1:1 to feed 1.5-liter of mini biodigesters. These different treatments are summarized in Table 1. 
Table 1

The different treatments formulated

\begin{tabular}{|lllll|}
\hline Treatments & $\begin{array}{l}\text { Cow } \\
\text { dung } \\
\text { (CD in } \\
\text { Kg) }\end{array}$ & $\begin{array}{l}\text { Ordinary } \\
\text { Water } \\
\text { (Wa in } \mathrm{L})\end{array}$ & $\begin{array}{l}\text { Filtrate without } \\
\text { biochar } \\
\text { (Fi without Bc in } \mathrm{L})\end{array}$ & $\begin{array}{l}\text { Filtrate with } \\
\text { biochar } \\
\text { (Fi with Bc in } \mathrm{L})\end{array}$ \\
\hline $\mathrm{CD}+\mathrm{Wa}$ (Control) & 0.75 & 0.75 & 0 & 0 \\
\hline $\mathrm{CD}+\mathrm{Fi}$ without Bc & 0.75 & 0 & 0.75 & 0 \\
\hline $\begin{array}{l}\mathrm{CD}+\mathrm{Fi} \text { without } \mathrm{Bc}+ \\
\text { Wa }\end{array}$ & 0.75 & 0.375 & 0.375 & 0 \\
\hline $\mathrm{CD}+\mathrm{Fi}$ with Bc & 0.75 & 0 & 0 & 0.75 \\
\hline $\mathrm{CD}+\mathrm{Fi}$ with Bc +Wa & 0.75 & 0.375 & 0 & 0.375 \\
\hline
\end{tabular}

\subsection{Evaluation of biogas production}

The quantity of biogas produced by the different mini-digesters was measured every 2 days during the hydraulic retention time of 30 days. This was done according to the method used by Tizé et al. (2015). The biogas generated was quantified using polyethylene bags to collect the gas produced by each bioreactor. The bag containing gas was carefully tied and placed in a $1000 \mathrm{~mL}$ beaker and held at the bottom by a funnel. The gas from the plastic occupies a certain volume of the beaker. This was topped up to $1000 \mathrm{~mL}$ with tap water while ensuring that the gas bag was fully submerged. After removing the gas bag and the funnel, the water level in the beaker drops. The difference in volume corresponds to the volume occupied by the gas, the gas bag and the funnel $(\mathrm{V})$. Thus, an empty bag of the same kind and the funnel are again placed at the bottom of the beaker and occupy a volume. With a known amount of water in a test tube, the volume is adjusted again to $1000 \mathrm{~mL}$. The amount of water used in the latter case constitutes the volume of gas $(\mathrm{Vg})$ contained in the plastic [19].

Production was monitored and regularly quantified throughout the anaerobic digestion cycle. The auto ignition test of the produced gas was performed at each quantification of the production. The digestion took place in a mesophilic zone, which is favourable for methanisation [20] .

\subsection{The $\mathrm{pH}$ measurement}

The $\mathrm{pH}$ was measured with an EUTECH INSTRUMENTS pH meter twice a week. The probe is introduced into the beaker containing the solution taken from the mini-bioreactor through a pipe that is arranged in it and the $\mathrm{pH}$ value is valid when the $\mathrm{pH}$-meter displays 'READY'. The $\mathrm{pH}$ variation curves of the different solutions combined with the histograms illustrating the biogas production kinetics were plotted using Excel software.

\subsection{Statistical analysis of data}


The collected data were subjected to statistical analysis using Microsoft Office Excel. The analysis consisted of calculating the mean and standard deviation of biogas production. The same software allowed us to draw the curves.

\section{Results Et Discussion}

\subsection{Filtration of Digestate}

For the first generation of mini-bioreactors, we carried out 02 filtrations of 15 litres of digestate, 7.5 liters per filter type. In the second generation, $22.5 \mathrm{~L}$ of digestate from the first generation was filtered. The filtration was carried out according to the treatments carried out in the first generation. It can be seen that the filtrate flow rate is $0.17 \mathrm{~L} / \mathrm{h}$ when using a filter without a biochar layer and It is $0.2 \mathrm{~L} / \mathrm{h}$ in the filter with a biochar layer. From this, it appears that the biochar would improve the flow rate in a filtration. The flow rates of our two filters are slow compared to the biosand filter used by Budeli (2021). In the 2nd generation, the flow rate was $0.15 \mathrm{~L} / \mathrm{h}$ in each. On average, $88.88 \%$ of the water used to dilute the dung was recovered for the second generation biogas production. And the solid product is a good organic fertilizer [21, 22]. It contains phosphorus $\left(\mathrm{P}_{2} \mathrm{O}_{5}\right)$ and potassium $\left(\mathrm{K}_{2} \mathrm{O}\right)[23-24,25]$. Many researchers continued to study the effect of biogas effluent on plant growth [26]. The appearance of the filtrate obtained is shown in Fig. 2.

\subsection{Biogas production}

\section{i. The first generation}

After monitoring the evolution of biogas production and $\mathrm{pH}$ over one month, we analyzed the data collected. Indeed, the biogas produced is stored in plastic (fig.3a.), then evaluated and tested for flammability. The flammability test of the gas would therefore give a more accurate idea of the nature of the gas, i.e. whether the gas obtained is indeed methane-rich biogas. The positive test produces a blue flame as shown in Fig. 3b.

The cumulative average production of the five 1 st generation treatments were calculated. Figure 4 . illustrates the kinetics of biogas production using recycled water from the first digestate as previously indicated.

The Fig. 4. above shows that the highest cumulative production of the 1st generation is slightly less than $6500 \mathrm{~mL}$. In fact, in this generation of biogas productions, the cow dung treatment diluted with filtrate without biochar $(C D+F i$ without $\mathrm{Bc}$ ) recorded the highest biogas volume $(6369 \mathrm{~mL})$. It is $7.9 \%$ and $47 \%$ higher than the productions of the cow dung diluted with ordinary water and filtrate from the filter with a biochar layer $(\mathrm{CD}+\mathrm{Fi}$ with $\mathrm{Bc}+\mathrm{Wa})$ and the control respectively. Therefore, it appears that recycling the filtrate to the first generation improves the substrate productivity by almost two times compared to the use of tap water. As for the effects of filtrate with biochar on production, it appears that it favors a better 
production during the first 16 days of anaerobic digestion. In general, we found that recycling the water contained in the digestate to re-dilute the cow dung for biogas production has a positive influence on the yield. The following Fig. 4 shows the evolution of the average biogas yields in the first generation as a function of $\mathrm{pH}$ and HRT.

In Fig. 5. above, we can see overall that in addition to promoting better production, the filtrates help to maintain the digestion $\mathrm{pH}$ around neutrality. It varies between 6.5 and 7.5 , which is the best $\mathrm{pH}$ range for anaerobic digestion [27],[19]. The acidification phase is almost absent. However, during the first week of anaerobic digestion of cow dung, the $\mathrm{pH}$ drop from 7.5 to 6 was observed. This was also evident in the mini-biodigesters that received ordinary water (Fig. 5c, d, and e). Dilution of the substrate mainly with ordinary water or in combination with the filtrate caused a drop in $\mathrm{pH}$ to around 5 during the first 10 days of anaerobic digestion.

\section{ii. The second generation}

The curves in Fig. 6. are obtained from the average values of biogas production in the 2nd generation.

In contrast to the first generation, Fig. 6 . shows that during the second generation, the cow dung treatment diluted with ordinary water was the most productive $(4647 \mathrm{~mL})$ throughout the 28 days of HRT. This was followed by the one diluted with filtrate without biochar $(4311 \mathrm{~mL})$. However, the difference was $7.7 \%$. The poorest performance was observed in the treatments that were diluted with biochar filtrate. Its production was $30 \%$, this values is lower than that of the best treatment (cow dung + ordinary water). This could be explained by the fact that water recycled several times would have become less and less suitable for anaerobic digestion. The accumulation of nutrients in the recycled water would therefore have had an impact on the productivity of these treatments.

\section{Conclusion}

At the end of this study, it appears that there is a good possibility to recycle the water contained in the digestate for the reproduction of biogas. With the help of a simple filter made of sand, gravel, cotton, and to a certain extent biochar, filtration is effective. In this way, about $89 \%$ of the water used in the dilution process can be recovered and recycled. After a one-month follow-up of the first generation of these reused water in the mini digesters, we notice that it improves the biogas production yield (qualitatively and quantitatively) compared to the use of tap water. It is also find that the $\mathrm{CD}+\mathrm{Fi}$ dilution without $\mathrm{Bc}$ in the first generation produces more than the others $(6369 \mathrm{~mL})$. However, when the same water is reused for the third time in the biodigester (2nd generation), the production drops. Indeed, at the second generation, the $\mathrm{CD}+\mathrm{Wa}$ treatment has a better production $(4647 \mathrm{~mL})$ compared to the others. We also found that the use of biochar as a filter layer did not lead to an increase in biogas production. Therefore, the filtered water using biochar would have a negative effect on biogas production. This study also shows that $\mathrm{pH}$ has a significant influence on biogas production. For good production, the $\mathrm{pH}$ should be kept around 7 which is neutral. 


\section{Declarations}

\section{Availability of supporting data}

Les données obtenues ainsi les matériels lors de cette étude sont disponibles au laboratoire et à la bibliothèque des énergies renouvelables de l'Ecole Nationale Polytechnique de Maroua. Ces données sont également disponible sur l'adresse du responsable de cette étude tizekodjoel@yahoo.fr.

\section{References}

1. Utama, N.A., Fathoni, A.M., Kristianto, M.A., McLellan, B.C.: 'The End of Fossil Fuel Era: Supplydemand Measures through Energy Efficiency'. Procedia Environ. Sci. 20, 40-45 (2014). doi:10.1016/j.proenv.2014.03.007

2. Madon, G., 'Le bois, énergie de première nécessité en Afrique', Afr. Contemp., vol. № 261-262, no. 1, pp. 201-222, 2017, doi: 10.3917/afco.261.0201

3. Muller, C., Yan, H.: 'Household fuel use in developing countries: Review of theory and evidence'. Energy Econ. 70, 429-439 (Feb. 2018). doi:10.1016/j.eneco.2018.01.024

4. FAO, 'Foresterie urbaine et périurbaine en Afrique. Quelles perspectives pour le bois-énergie?', Doc. Trav. Sur For. Urbaine Périurbaine, no. 4, p. 95 page. Rome, 2010

5. Jiagho, E.R., Banoho, L.-P.-R.K., 'Facteurs de déforestation et de la dégradation du couvert ligneux dans le Parc National de Waza et sa périphérie, Cameroun', p. 24, 2021

6. Institut National de la Statistique (INC): and International Coaching Federation (ICF), 'Enquête Démographique et de la Santé du Cameroun 2018', INS et ICF, Yaoundé, Cameroun et Rockville, Maryland, USA, 2020

7. Folefack, D.P., Abou, S., 'Commercialisation du bois de chauffe en zone sahélienne du Cameroun', Sécheresse, vol. 20, no. 3, pp. 312-318, Jul. 2009, doi: 10.1684/sec.2009.0193

8. Tunk, C., Hoefsloot, H., Mougou, J.: 'Evaluation du potentiel de restauration des paysages forestiers au Cameroun', Rapport Final 18, 2016

9. MINFOF: 'Stratégie de modernisation de la chaine de valeur bois-énergie dans la Région de l'Extrême Nord', Ministère des Forêts et de la faune. Yaoundé, Cameroun (2014)

10. Fatouma, Z.L.: 'Analyse Rapide genre-déplacement de populations dans les arrondissements de Tokombéré et Mora-Extrême nord Cameroun', Care, 2015. [Online]. Available: www.careevaluation.org

11. Yopo, D.R., Mathias, F., Roger, N.: 'Vulnérabilité des systèmes d'approvisionnement en Eau Face aux Risques Climatiques en Zone Soudano-Sahélienne: Cas De Mogode, Extrême-Nord Cameroun'. J. Cameroon Acad. Sci. 12(2), 14 (2015)

12. Wassouni, F.: 'L'innovation dans le secteur de l'artisanat africain: l'émergence et le développement de l'artisanat des cornes de bœufs á Maroua dans l'extrême nord du Cameroun'. Marché Organ. 3(24), 145-172 (2015). doi:10.3917/maorg.024.0145 
13. Yopo, R.D., Fru, M.F., Kanouo, B.M.D.: 'Assessment of the Level of Drinking Water Supply Service Provision: Case study of Mayo-Tsanaga River Sub-Basin in Cameroon'. Int. J. Eng. Res. 10(07), 6 (2021)

14. Budeli, P., Moropeng, R.C., Momba, M.N.B.: 'Improvement of biosand filtration systems using silverimpregnated clay granules'. J. Water Process. Eng. 41, 102049 (Jun. 2021). doi:10.1016/j.jwpe.2021.102049

15. Clark, P.A., Pinedo, C.A., Fadus, M., Capuzzi, S.: 'Slow-sand water filter: Design, implementation, accessibility and sustainability in developing countries'. Med. Sci. Monit. 18(7), RA105-RA117 (Jun. 2012). doi:10.12659/MSM.883200

16. Kumar, G., et al.: 'Empirical evaluation of sand filters to evolve practical designs for artificial recharge through dry wells'. J. Hydrol. 593, 125839 (Feb. 2021). doi:10.1016/j.jhydrol.2020.125839

17. CAWST: 'Manuel du Filtre Biosable Conception, Construction, Installation, Fonctionnement et Entretien'. Centre for Affordable Water and Sanitation Technology (2010)

18. EPA: 'Filtre à Sable Lent', DINEPA, République d’Haïti. Extrait de Référentiel Technique National (2013)

19. TIZE KODA, J., DJOULDE, D.R., NGAKOU, A.: 'Influence du prétraitement mécanique et biologique des feuilles mortes de neem (azadirachta indica) sur la production du biogaz [Influence of mechanical and biological pretreatment of dead neem leaves (azadirachta indica) on biogas production]'. Int. J. Innov. Sci. Res. 16(2), 505-513 (2015)

20. Abdoul-Aziz, I., Telesophore, K., Kemausuor, F.: 'Biogas optimisation processes and effluent quality: A review', Biomass Bioenergy, no. 133, p. 11, Dec. 2019, doi:https://doi.org/10.1016/j.biombioe.2019.105449

21. Leno, N., et al.: 'Thermochemical digestate fertilizer from solid waste: Characterization, labile carbon dynamics, dehydrogenase activity, water holding capacity and biomass allocation in banana'. Waste Manag. 123, 1-14 (Mar. 2021). doi:10.1016/j.wasman.2021.01.002

22. de Araujo, G.J.F., de Oliveira, S.V.W.B., de Oliveira, M.M.B., 'Economic Analysis of Internal Circulation Biodigesters and Vinasse Concentrators for the Generation of Electricity, Fertilizers, and Carbon Credits in Various Brazilian Economic Scenarios', BioEnergy Res., vol. 12, no. 4, pp. 1164-1186, Dec. 2019, doi: 10.1007/s12155-019-10030-9

23. Satyanarayan, S., Murkute, P., Ramakant, 'Biogas production enhancement by Brassica compestries amendment in cattle dung digesters', Biomass Bioenergy, vol. 32, no. 3, pp. 210-215, Mar. 2008, doi: 10.1016/j.biombioe.2007.09.008

24. Koszel, M., Lorencowicz, E.: 'Agricultural Use of Biogas Digestate as a Replacement Fertilizers'. Agric. Agric. Sci. Procedia. 7, 119-124 (2015). doi:10.1016/j.aaspro.2015.12.004

25. Song, S., et al., 'Food-waste anaerobic digestate as a fertilizer: The agronomic properties of untreated digestate and biochar-filtered digestate residue', Waste Manag., vol. 136, pp. 143-152, Dec. 2021, doi: 10.1016/j.wasman.2021.10.011

26. Wikanya, P., Preeyanan, S., Watcharawit, R., Duangrat, S., Loetchai, C., Matta, F.B.: ‘Biogas Production from Peels and Seeds of Longan (Dimocarpus Iongan Lour.) in Anaerobic Ferment System'. Int. J. 
Agric. Technol. 13(7.1), 9 (2017)

27. Himel, T.F., Uddin, S.S., Kabir, F., Shatil, A.H.: 'Analysis of $\mathrm{pH}$ factor of Small Range Biogas Production with Local Ingredients'. Cardiff J. 33, no. EM556L, p. 8 (2018)

\section{Figures}

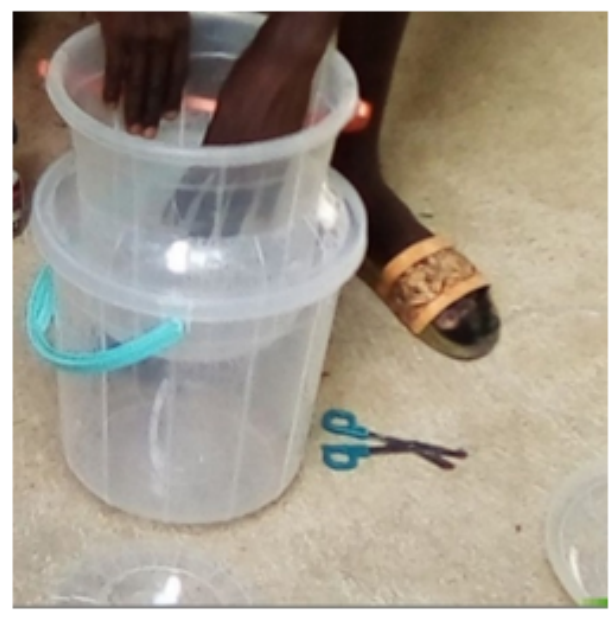

(a)

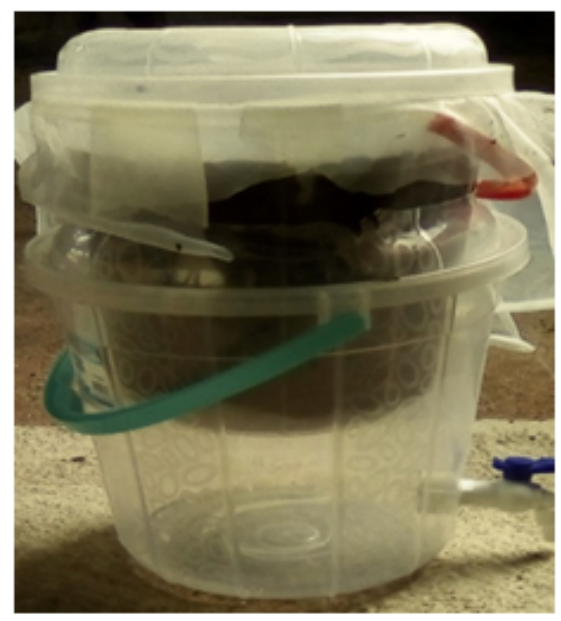

(b)

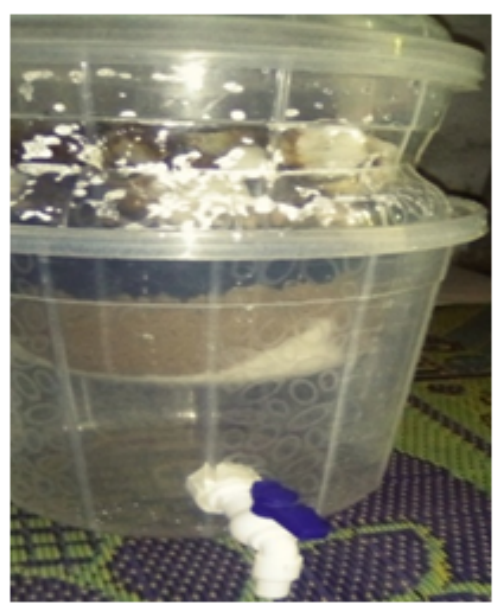

(c)

\section{Figure 1}

Experimental filter (a) before the filter layers are inserted, (b) filter without a biochar layer, (c) filter with a biochar layer.
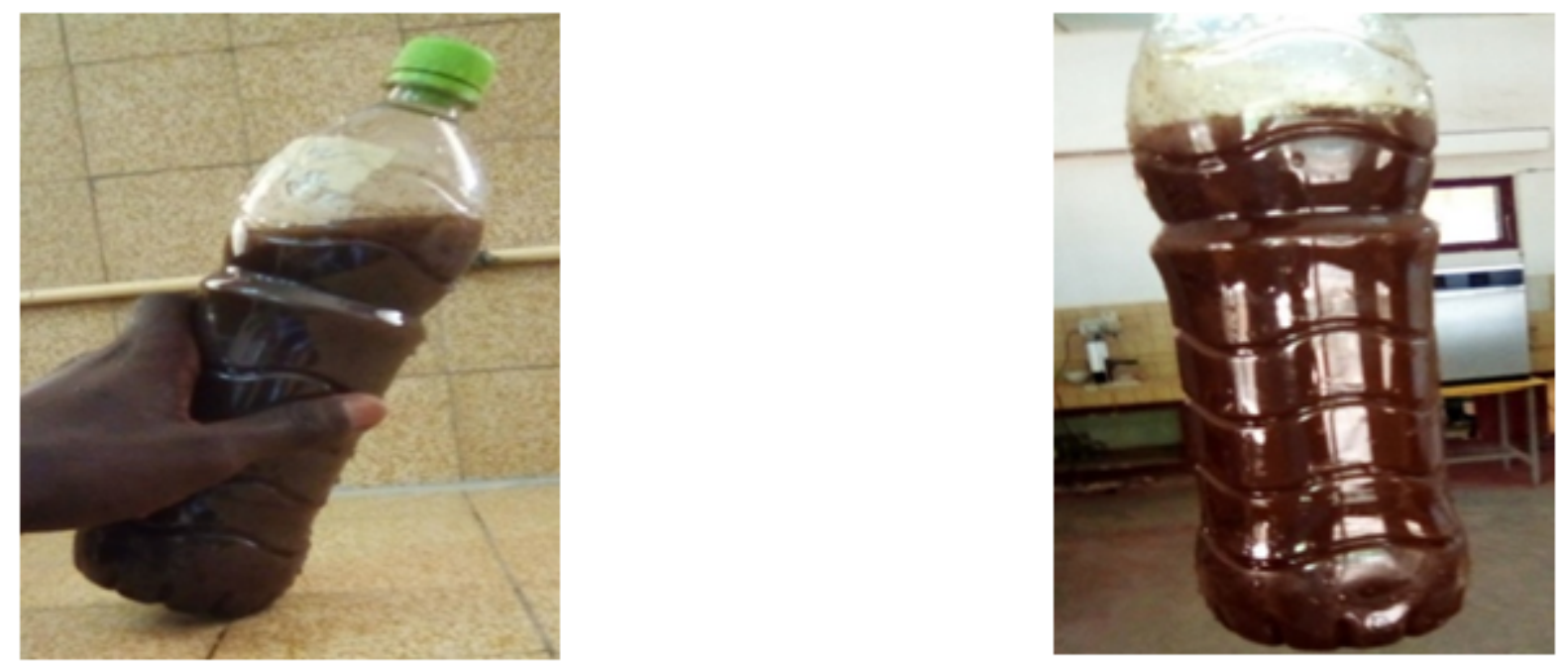

\section{Figure 2}

Digestate filtrate to be recycled for biogas production 


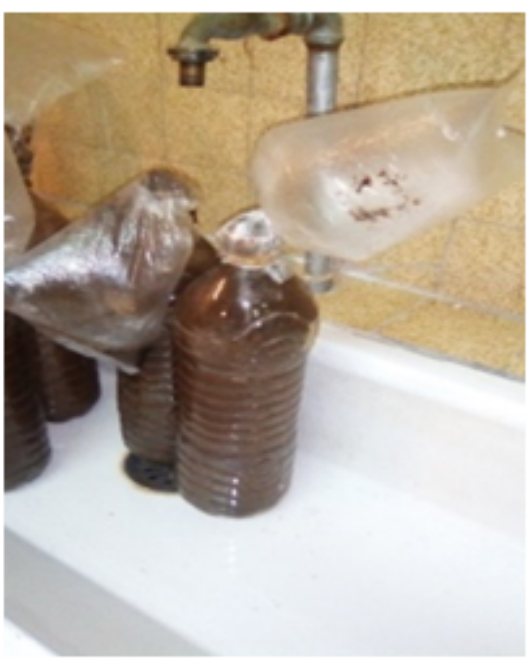

(a)

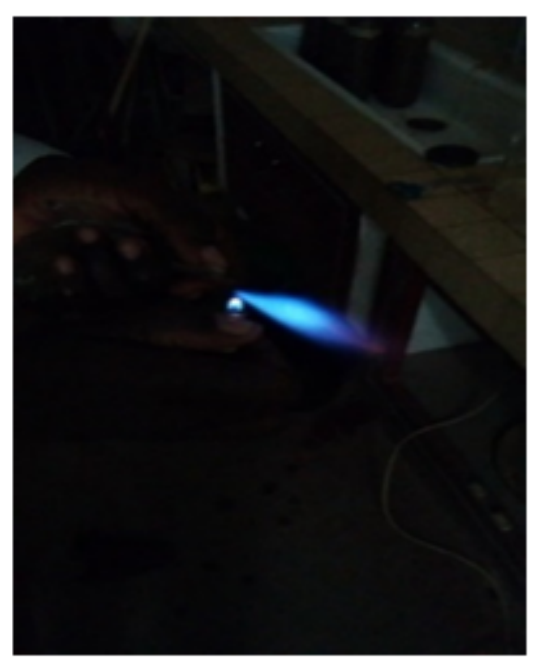

(b)

\section{Figure 3}

Biogas Production: a) quantity produced in polyethylene plastics in two days; $b$ ) flame color of the biogas produced

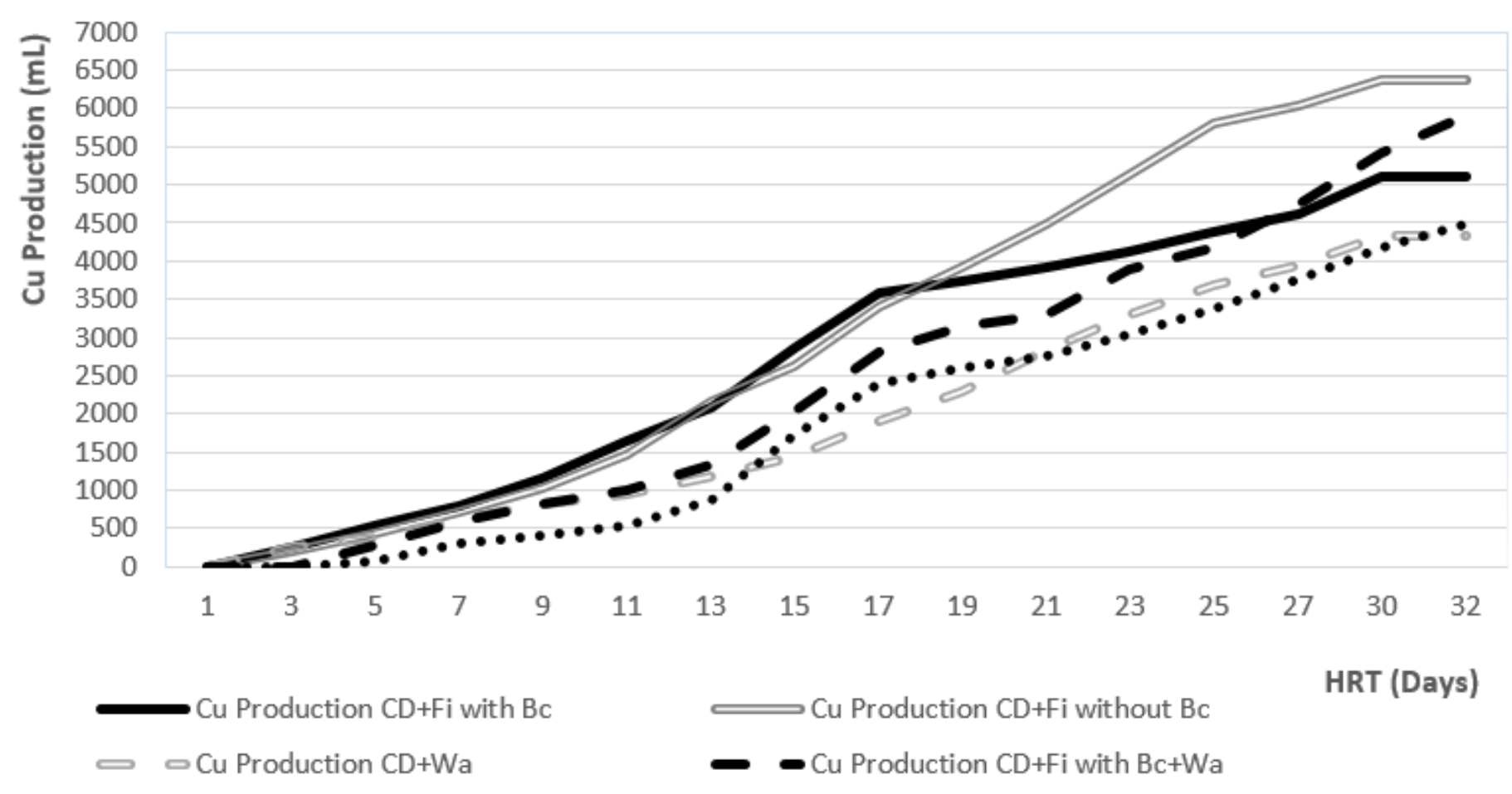

Figure 4 


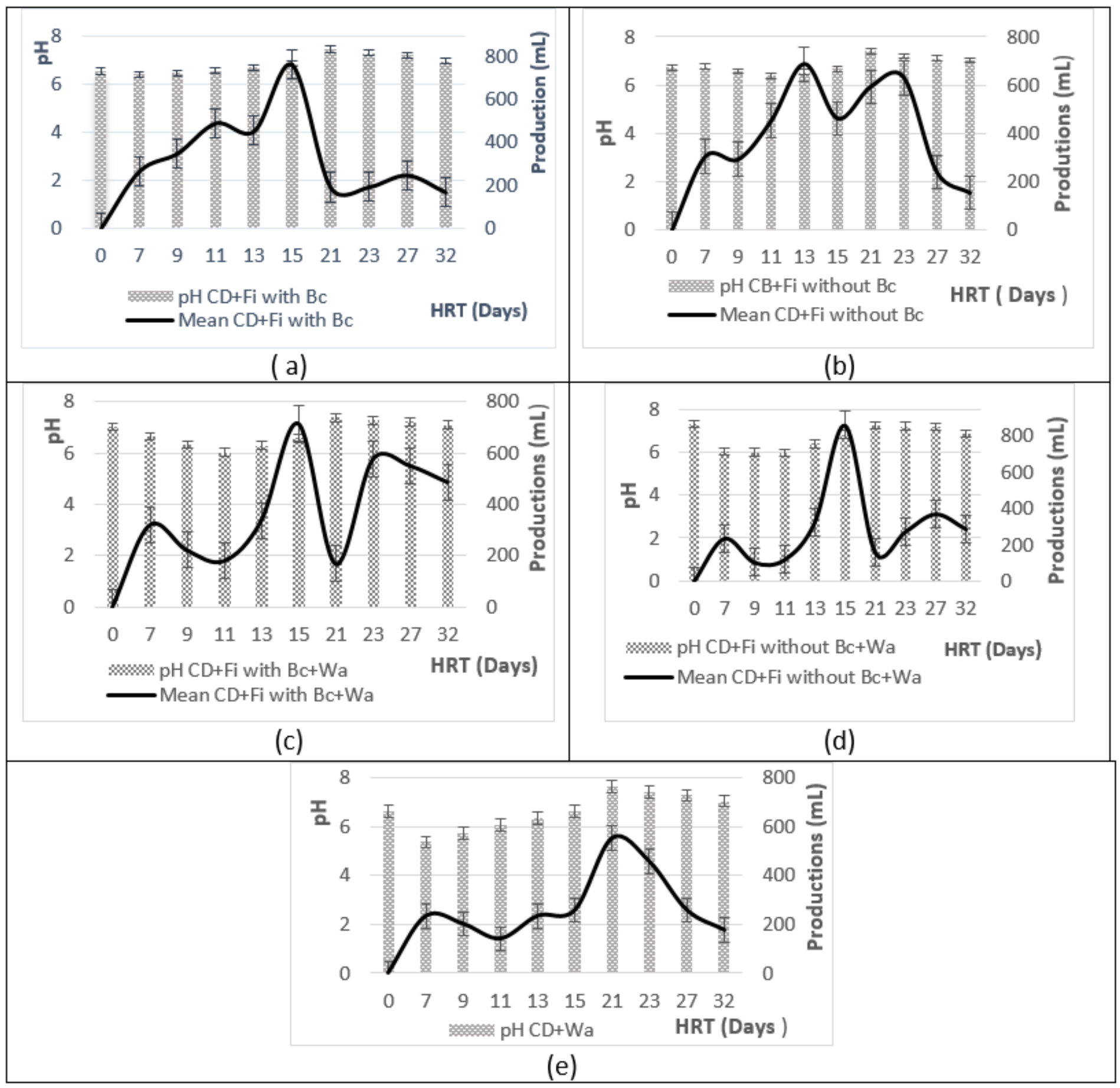

Figure 5

Changes in production and $\mathrm{pH}$ of the first generation: (a) cow dung and filtrate treatment with biochar, (b) cow dung and filtrate treatment without biochar, (c) cow dung and running water, (d) cow dung and filtrate treatment with biochar and running water, (e) cow dung and filtrate treatment without biochar and running water 


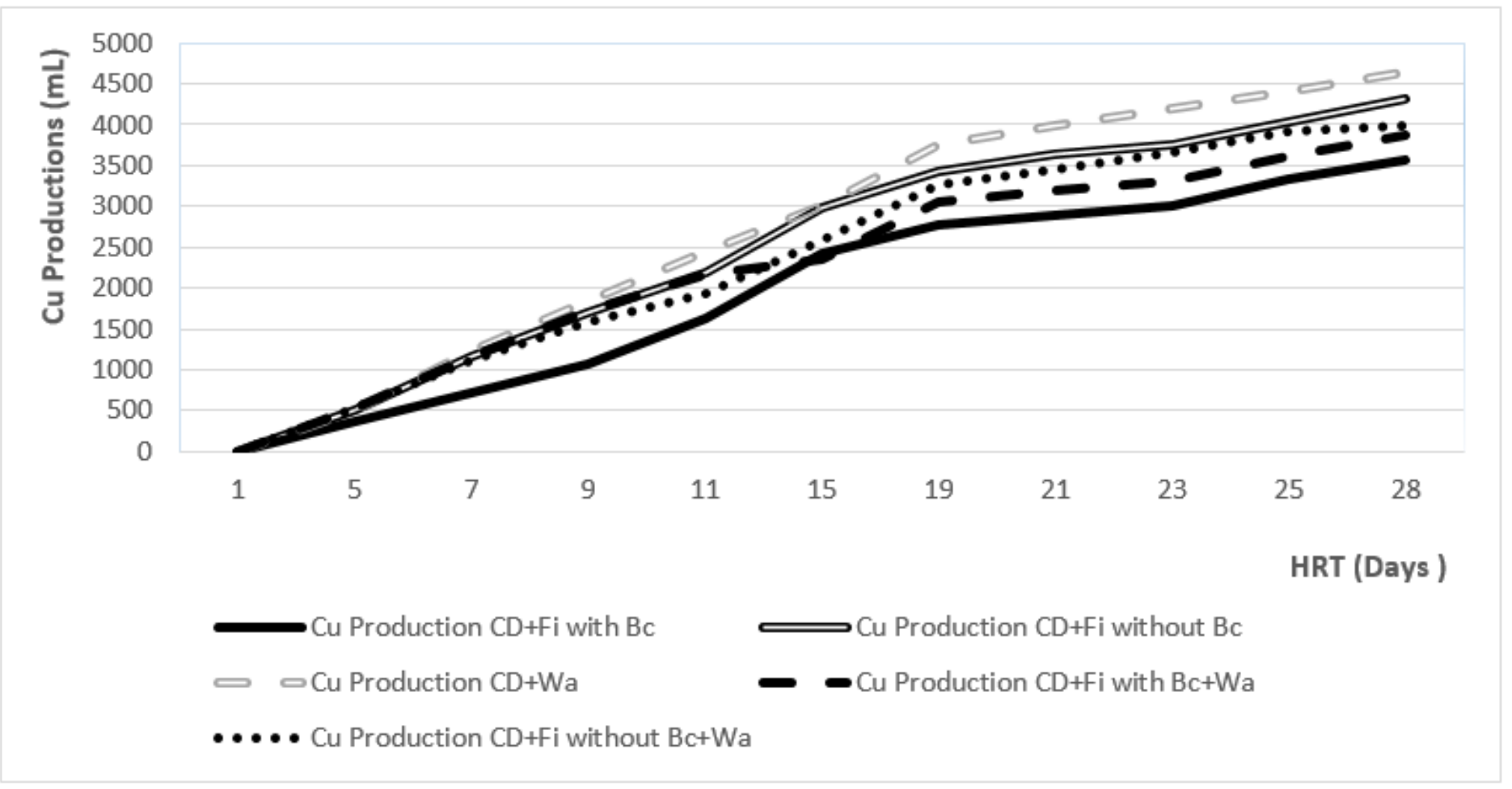

Figure 6

Kinetic of cumulative biogas productions of the $2^{\text {nd }}$ generation

\section{Supplementary Files}

This is a list of supplementary files associated with this preprint. Click to download.

- Highlightsofarticledigestate.docx 